\title{
Inducible nitric oxide synthase in human lymphomononuclear cells activated by synthetic peptides derived from extracellular matrix proteins
}

\author{
L.A. Pérez-Mediavilla ${ }^{a}$, M.J. López-Zabalza ${ }^{a}$, M. Calonge ${ }^{a}$, L. Montuenga ${ }^{b}$, \\ N. López-Moratalla ${ }^{\mathrm{a}}$, E. Santiago ${ }^{\mathrm{a}, *}$ \\ ${ }^{a}$ Department of Biochemistry, University of Navarra, Pamplona, Spain \\ ${ }^{\mathrm{b}}$ Department of Cytology and Histology, University of Navarra, Pamplona, Spain
}

Received 16 September 1994; revised version received 22 November 1994

\begin{abstract}
Synthetic peptides with sequences present in extracellular matrix proteins are capable of causing the expression of the inducible form of nitric oxide synthase (iNOS), detected by immunocytochemistry, and the release of NO by human lymphomononuclear cells incubated in their presence. Active peptides are 15-mers containing a characteristic 2-6-11 motif in which the amino acid residue at position 2 is Leu, Ile, Val, Gly, Ala or Lys; the residue at position 6 is always Pro; and residue 11 is Glu or Asp. The induction of iNOS in human monocytes and macrophages could be involved in the cytotoxicity against tumor cell lines also elicited by these peptides.
\end{abstract}

Key words: Nitric oxide synthase (inducible); NO release; Human lymphomononuclear cell; Immunocytochemistry; Extracellular matrix protein

\section{Introduction}

The production of nitrate and nitrite by mammalian cells was first demonstrated in vitro in mouse peritoneal macrophages in response to lipopolysaccharide [1]. Later the release of nitric oxide (NO) by the same cells was reported $[2,3]$. It is now well established that rodent macrophages possess an inducible nitric oxide synthase (iNOS) [4] and also that mouse macrophages can be stimulated to release nitric oxide by agents such as cytokines, microbial products and tumor cells [5,6]. It is now widely accepted that NO synthesized from L-arginine in a reaction catalyzed by NOS is an antimicrobial and antitumoral effector system of mononuclear cells from rodents [7-9]. However, it is still controversial whether an analogous system is also present in human macrophages [10-16].

In a previous article [17] we reported that peptides with a definite structural pattern (2-6-11 motif) have the ability to activate human monocytes and to induce cytotoxicity against tumor cell lines when lymphomononuclear cells are incubated in the presence of these immunomodulators. These peptides are 15-mers in which the amino acid residue at position 2 is Leu, Ile, Val, Gly, Ala or Lys; the residue at position 6 is always Pro; and the residue at position 11 is Glu or Asp.

The aim of the present study was to examine if the induction of iNOS and NO production could be elicited by peptides with

\footnotetext{
*Corresponding author. Fax: (34) (48) 105649.

Abbreviations: iNOS, inducible nitric oxide synthase; SpA, Staphilococcus aureus protein A; LPS, lipopolysaccharide; NMMA, $N^{\mathrm{G}}$-monomethyl-L-arginine.
}

the pattern conferring immunomodulating activity. The results clearly show that peptides derived from Staphylococcus aureus protein A (SpA) or from extracellular matrix proteins (ECM) were capable of bringing about the induction of NOS and the production of NO.

\section{Materials and methods}

\subsection{Cell culture}

Lymphomononuclear cells were obtained from peripheral blood of healthy donors following the technique described by Boyum [18]. Blood lymphomononuclear cells were incubated at $2 \times 10^{6}$ per $\mathrm{ml}$ in RPMI1640 medium (Biochrom, Berlin, Germany), supplemented with $2.5 \%$ of autologous serum, $2 \mathrm{mM}$ L-glutamine, penicillin $(100 \mathrm{U} / \mathrm{ml})$ and streptomycin $(100 \mu \mathrm{g} / \mathrm{ml})$ in a $5 \% \mathrm{CO}_{2}$ humidified atmosphere.

\subsection{Peptide synthesis}

Peptides were synthesized by the solid phase method of Merrifield [19], with the Fmoc modification [20].

\subsection{Immunocytochemistry}

After incubation cells were pelleted by centrifugation and fixed in a formaldehyde-picric mixture [21] for $24 \mathrm{~h}$ at $4^{\circ} \mathrm{C}$. Cells were then washed in $0.1 \mathrm{M}$ phosphate buffer, $\mathrm{pH} 7.3$, resuspended in $6 \%$ agarose, dehydrated and embedded in paraffin. Cells were sectioned at a thickness of $5 \mu \mathrm{m}$ and treated by the avidin-biotinylated peroxidase complex technique [22]. After removing the paraffin, intrinsic peroxidase was blocked by treatment of the sections with a solution of methyl alcohol containing $3 \% \mathrm{H}_{2} \mathrm{O}_{2}$ for $30 \mathrm{~min}$. Background blocking was performed with 1:20 normal pig serum for 30 min prior to incubation with the specific primary antiserum, which was carried out for $20 \mathrm{~h}$ at $4^{\circ} \mathrm{C}$. After rinsing with Tris-buffered saline (TBS) $(0.05 \mathrm{M}$ Tris, pH 7.36, $0.55 \mathrm{M}$ $\mathrm{NaCl}$ ) the sections were incubated with biotinylated pig anti-rabbit IgG (Dakopatts, E353, Glostrup, Denmark) at a 1/200 solution for $30 \mathrm{~min}$. Following a second rinsing in TBS, sections were further incubated with the avidin-biotinylated complex (1:100 Tris dilution, Dakopatts, E355) for $30 \mathrm{~min}$. After a final rinsing, peroxidase activity was visualized using diaminobenzidine $(50 \mathrm{mg}$ per $100 \mathrm{ml})$ and $\mathrm{H}_{2} \mathrm{O}_{2}(10 \mu \mathrm{l}$ per $50 \mathrm{ml}$ of solution). Sections were lightly counterstained with Harris's hematoxylin. A polyclonal rabbit antibody against a 26 amino acid synthetic peptide (QNGSPQLLTGTAQNVPESLDKLHVTC) chosen from the published sequence of mouse macrophage iNOS [23] was used for the present study. The specificity of this antibody for the detection of iNOS has been previously shown [24]. Another polyclonal antibody against a synthetic fragment ( $\mathrm{p} 53$ ) of rat neural NOS [25] was also used for some of the control experiments. Both antisera were courtesy of $V$. Riveros-Moreno and S. Moncada (Wellcome Research Labs., Beckenham, Kent, UK). The specificity of the immunoreaction was tested by (i) preabsorption of the antiserum with the synthetic antigenic peptide ( $10 \mathrm{nmol} / \mathrm{ml}$ of diluted antiserum) and (ii) the use of preimmune serum of the same rabbit from which the antibody was obained, diluted $1 / 20$, instead of the primary antiserum.

\subsection{Determination of nitrite and nitrate}

When nitrite or nitrate was to be determined, the medium was supplemented with $0.5 \mathrm{mM}$ L-arginine. Cell free supernatants were collected after incubation for $48 \mathrm{~h}$ and stored at $-20^{\circ} \mathrm{C}$ until analysis. Nitrite 
concentration in the medium was quantitated by a colorimetric assay based on the Griess reaction [26]. Nitrate concentration was determined by a UV method using a commercial kit (Boehringer-Mannheim).

\section{Results}

Peptides selected for this study contained fifteen amino acid residues, fourteen of them representing sequences present in fibronectin [27], laminin A [28], laminin B1 [29], $\alpha_{1}$-collagen IV [30] or $S$. aureus protein A [31]. En extra valine residue was always added in the $\mathrm{C}$-terminus for synthesis convenience.

\subsection{Immunocytochemical detection of iNOS}

Human lymphomononuclear cells incubated for 7 days in the presence of fibronectin or any of the immunomodulating peptides containing the 2-6-11 motif (Table 1) were immunoreactive for iNOS when antiserum against the inducible form of the enzyme was used. No immunoreactivity was observed if an antibody against the constitutive form of the enzyme was used. A clear difference in the number of cells stained with the iNOS antiserum can be observed when comparing sections of cells incubated with the inactive control peptide Pc (Fig. 1A) with those belonging to cells treated with the active peptide $\mathrm{P} 3$
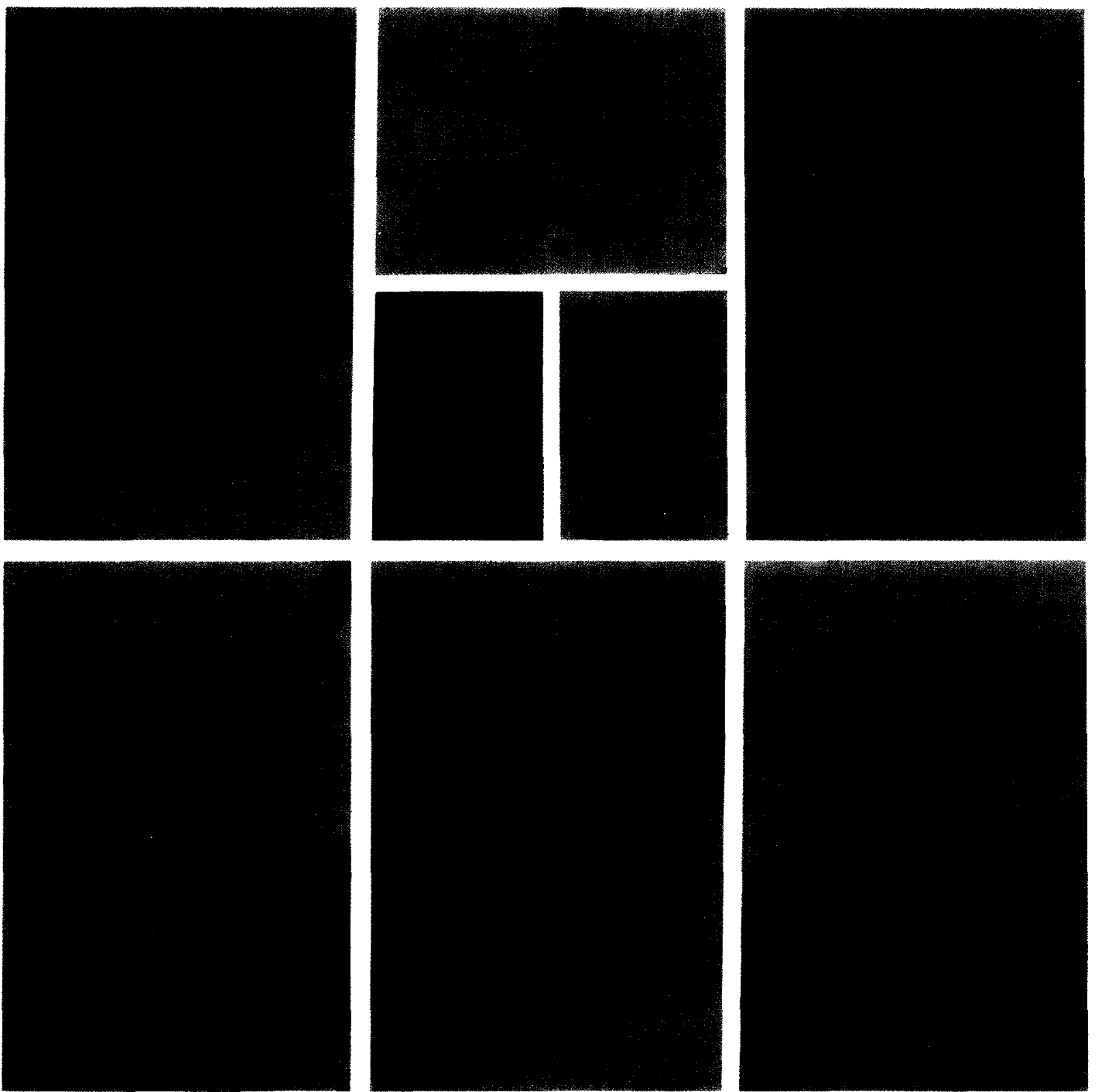

Fig. 1. Inducible nitric oxide synthase in human lymphomononuclear cells demonstrated by immunocytochemistry. (A) Cells incubated in the presence of inactive peptide Pc and stained for iNOS. No immunoreactivity can be observed. (B) Cells incubated in the presence of immunomodulating peptide P3 (top), fibronectin (bottom left) or active peptide Pa (bottom right) for 7 days and stained for iNOS. (C) Cells incubated in the presence of active peptide P3 for 7 days and stained for iNOS with antiserum previously preabsorbed with the corresponding specific antigen. The absence of immunoreactivity confirmed the specificity of the iNOS antiserum used. (D) Adherent cells recovered from lymphomononuclear cells incubated in the presence of inactive peptide Pc. No immunoreactivity can be observed. (E and F) Adherent cells, immunoreactive monocytes and macrophages, recovered from lymphomononuclear cells incubated in the presence of peptides $\mathrm{P} 3$ and $\mathrm{Pa}$, respectively. 
Table 1

Nitrite production by human lymphomononuclear cells incubated with immunomodulating peptides

\begin{tabular}{|c|c|c|c|c|c|}
\hline \multirow[t]{2}{*}{ Addition } & \multirow[t]{2}{*}{ Peptide sequence ${ }^{\mathrm{a}}$} & \multirow[t]{2}{*}{ Protein } & \multirow[t]{2}{*}{ Position $^{b}$} & \multicolumn{2}{|c|}{$\mathrm{NO}_{2}^{-}\left(\mathrm{nmol} / 10^{5}\right.$ cells $)$} \\
\hline & & & & Medium & NMMA \\
\hline None & & & & $0.80 \pm 0.3$ & $0.76 \pm 0.2$ \\
\hline Pl & KLGVRPSQGGEAPR & Fibronectin & $1088-1101$ & $4.83 \pm 0.3$ & $1.46 \pm 0.3$ \\
\hline $\mathrm{P} 2$ & IKGLKPGVVYEGQL & Fibronectin & $639-652$ & $4.62 \pm 0.3$ & $1.36 \pm 0.2$ \\
\hline P3 & IISCHPVGTDEEPL & Fibronectin & $2015-2028$ & $4.26 \pm 0.4$ & $1.37 \pm 0.3$ \\
\hline P4 & LRERNPEGCSECFC & Laminin A & $475-488$ & $3.97 \pm 0.3$ & $1.20 \pm 0.3$ \\
\hline P5 & MLRESPGGMREKGR & Laminin A & $1981-1993$ & $4.26 \pm 0.4$ & $1.31 \pm 0.3$ \\
\hline P6 & GISTGPMKKVDDII & Laminin B1 & $155-168$ & $3.98 \pm 0.3$ & $1.33 \pm 0.2$ \\
\hline P7 & QALASPGSCLDEFR & $\alpha_{1}$ Collagen IV & $1569-1582$ & $4.78 \pm 0.3$ & $1.30 \pm 0.3$ \\
\hline P8 & EILMNPNLNEEQRN & $\mathrm{SpA}$ & $18-31$ & $4.46 \pm 0.3$ & $1.39 \pm 0.3$ \\
\hline P9 & SLKDDPSVSKEILA & SpA & $210-223$ & $4.53 \pm 0.4$ & $1.35 \pm 0.3$ \\
\hline $\mathrm{Pc}$ & $A D A Q Q N K F N K D Q Q S^{C}$ & $\mathrm{SpA}$ & 114 & $0.76 \pm 0.3$ & $0.71 \pm 0.3$ \\
\hline $\mathrm{Pa}$ & NVLGAPKKLNESQA & & & $4.84 \pm 0.3$ & $1.36 \pm 0.3$ \\
\hline LPS & & & & $5.26 \pm 0.4$ & $1.61 \pm 0.3$ \\
\hline
\end{tabular}

The results are means \pm S.E.M. for duplicates from one of five similar experiments. Concentration of peptides in the medium was $30 \mu \mathrm{g} / 10^{6}$ cells, and that of LPS $10 \mu \mathrm{g} / 10^{6}$ cells. When present, NMMA concentration was $1 \mathrm{mM}$. Incubation time, $48 \mathrm{~h}$.

${ }^{2}$ An extra valine residue, not shown, was added to the C-terminus for synthesis convenience.

${ }^{b}$ Numbering of the amino acid residues at the corresponding protein.

"Inactive control peptide.

dSynthetic non-natural immunomodulating peptide.

(Fig. 1B, top), fibronectin (Fig. 1B, bottom left) or active peptide $\mathrm{Pa}$ (Fig. 1B, bottom right) under the same conditions. Preabsorption of antiserum with the corresponding antigen completely abolished immunostaining (Fig. 1C). On a morphological basis the vast majority of stained cells could be considered as monocytes and macrophages. This point received further support when monocytes, which spontaneously adhered to the culture plates during the incubation, were scraped off after removing the supernatant containing non-adherent cells. Monocytes were then resuspended in a small volume of incubation medium and processed as the entire lymphomononuclear population (Fig. 1D-F). Adherent cells recovered from lymphomononuclear cells which had been incubated with inactive peptide Pc showed no immunoreactivity (Fig. ID). However, monocytes and macrophages were clearly immunoreactive if recovered cells had been incubated in the presence of peptide P3 (Fig. 1E) or active peptide Pa (Fig. 1F).

\subsection{NO release}

Table 1 shows the accumulation of nitrite in the medium when human lymphomononuclear cells were incubated for $48 \mathrm{~h}$ in the presence of active peptides. The production of nitrite was very similar to that caused by LPS. No release took place when the incubation was carried out in the presence of an inactive control peptide, $\mathrm{Pc}$. The release of nitrite was inhibited when $N^{\mathrm{G}}$-monomethyl-L-arginine was present in the medium during the incubation. Nitrate was also detected in the medium when cells were incubated in the presence of active peptides or LPS (approximately $1.3 \mathrm{nmol}$ of nitrate $/ 10^{5}$ cells). The nitrate level was lower $\left(0.4 \mathrm{nmol} / 10^{5}\right.$ cells $)$ when cells were incubated in the absence of peptides or in the presence of the inactive peptide Pc.

\section{Discussion}

The production of NO by human monocytes after prolonged exposure to GM-CSF and TNF- $\alpha$ [10], INF- $\gamma$ and TNF- $\alpha$, or LPS [11], and an ensuing increase in NO-dependent phagocytic activity has been reported. It has also been described that after the spontaneous maturation of isolated monocytes to macrophages, reactive nitrogen intermediates are employed in mediating macrophage cytotoxicity [12]. The production of NO by monocytes in alcoholic liver disease [13], and the stimulation of NO release in vitro by human monocytes, when brought into contact with tumor cells, has also been reported [14]. More recently, expression of iNOS mRNA in human monocytes stimulated with LPS/IFN- $\gamma$ has been demonstrated [15]. However, doubts regarding the release of NO by human monocytes still remain, since other workers have been unable to detect products related to this nitrogen intermediate in cultures of these cells with cytokines or LPS [14-16]. Under our experimental conditions, using human lymphomononuclear cells, we have detected significant levels of nitrite and nitrate released to the medium. An explanation of these discrepancies could be that we were using the whole lymphomononuclear population, not isolated monocytes; and interactions between these cells and lymphocytes might play some role in the translation or activation of the enzyme.

The results now reported clearly demonstrate the expression of the inducible form of the enzyme nitric oxide synthase in human monocytes and macrophages present in a population of lymphomononuclear cells activated by short immunomodulating peptides. The production of $\mathrm{NO}$ seems to indicate that the enzyme detected by immnunocytochemistry was present in its active form. Since peptides with the described 2-6-11 motif are also inducers of cytotoxicity against tumor cell lines [17,32], it may be suggested that this effect could be mediated by the NO produced by the activated cells.

Acknowledgements: This work was supported by a research grant from Gobierno de Navarra, Spain. We thank M.A. Prado for his help and advice in the development of the immunochemical techniques.

\section{References}

[1] Stuehr, D.J. and Marletta, M.A. (1985) Proc. Natl. Acad. Sci. USA $82,7738-7742$.

[2] Stuehr, D.J. and Marletta, M.A. (1987) J. Immunol. 139, 518525. 
[3] Green, S.J., Crawford, R.M., Hockmeyer, J.T., Meltzer, M.S. and Nacy, C.A. (1990), J. Immunol. 145, 42904297.

[4] Lorsbach, R.B., Murphy, W.J., Lowenstein, C.J., Snyder, S.H. and Russell, S.W. (1993) J. Biol. Chem. 268, 1908-1913.

[5] Ding, A., Nathan, C.F. and Stuehr, D.J. (1988) J. Immunol. 141, $2407-2412$.

[6] Isobe, K.-i. and Nakashima, I. (1993) Biochem. Biophys. Res. Commun. 192, 499-504.

[7] Nathan, C.F. and Hibbs, J.B.J. (1991) Curr. Opin. Immunol. 3, 65-70.

[8] Liew, F.Y. and Cox, F.E.G. (1991) Immunoparasitol. Today 12, A17-21.

[9] Nathan, C. (1992) FASEB J. 6, 3051-3064.

[10] Denis, M. (1991) J. Leukoc Biol. 49, 380-387.

[11] Muñoz-Fernández, M.A., Fernández, M.A. and Fresno, M. (1992) Immunol. Lett. 33, 35-40.

[12] Martin, J.H.J. and Edwards, S.W. (1993) J. Immunol. 150, 34783486.

[13] Hunt, N.C.A. and Goldin, R.D. (1992) J. Hepatol. 14, 146150.

[14] Zembala, M., Siedlar, M., Marcinkiewicz, J. and Pryjma, J. (1994) Eur. J. Immunol. 24, 435-439.

[15] Reiling, N., Ulmer, A.J., Duchrow, M., Ernst, M., Flad, H.D. and Hauschildt, S. (1994) Eur. J. Immunol. 24, 1941-1944.

[16] Schneemann, M., Shoedon, G., Hofer, S., Blau, N., Guerrero, L. and Schaffner, A. (1993) J. Infect. Dis. 167, 1358-1363.

[17] López-Moratalla, N., López-Zabalza, M.J., Subirá, M.L., BorrásCuesta, F., Pérez-Mediavilla, L.A. and Santiago, E. (1994) Biochim. Biophys. Acta 1221, 153-158.

[18] Bøyum, A. (1983) Scand J. Immunol. 17, $429-436$.
[19] Merrifield, R.B. (1963) J. Am. Chem. Soc. 85, 2149-2155.

[20] Atherton, E., Logna, J.C. and Sheppard, C.R. (1981) J. Chem. Soc. Perkin Trans. 1, 538-546.

[21] Stefanini, M., De Martino, C. and Zamboni, L. (1967) Nature 216, 173-174.

[22] Hsu, S., Raine, L. and Fanger, H. (1981) J. Histochem. Cytochem. $29,577-580$.

[23] Lyons, C.R., Orloff, G.J. and Cunningham, J.M. (1992) J. Biol. Chem. 267, 6370-6374.

[24] Hamid, Q., Springall, D.R., Riveros-Moreno, V., Chanez, P., Howarth, P., Redington, A., Bousquet, J., Godard, P., Holgate, S. and Polak, J. (1993), Lancet 342, 1510-1513.

[25] Riveros-Moreno, V., Beddell, C., Moncada, S. (1993) Eur. J. Biochem. 215, 801-808.

[26] Green, L.C., Wagner, D.A., Glogowski, J., Skipper, P.L. Wishnok, J.S. and Tannenbaum, S.R. (1982) Anal. Biochem. 126 131-138.

[27] Skorstengaard, K., Jensen, M.S., Sahl, P., Petersen, T.E. and Magnusson, S. (1986) Eur. J. Biochem. 161, 447-453.

[28] Sasaki, M., Kleinman, H.K., Hubert, H., Dutzmann, R. and Yamada, Y. (1988) J. Biol. Chem. 208, 16536-16544.

[29] Pikkarainen, T., Eddy, R., Fukushima, Y., Byers, M., Shows, T. Pihlajaniemi, T., Saraste, M. and Tryggvason, K. (1987) J. Bio. Chem. 262, 10454-10462.

[30] Soininen, R., Haka-Risku, T., Prockop, D.J. and Tryggvason, K. (1987) FEBS Lett. 225, 188-194.

[31] Sjødahl, J. (1977) Eur. J. Biochem 73, 343-351

[32] López-Moratalla, N., Calonge, M.M., López-Zabalza, M.J., Pérez-Mediavilla, L.A., Subirá, M.L. and Santiago, E. (1994) Biochim. Biophys. Acta (In press). 